\title{
HAK ASASI PEREMPUAN DALAM ISLAM
}

\author{
Nazar Naamy ${ }^{1}$ \\ nazarnaamy72@uinmataram.ac.id
}

\begin{abstract}
Abstrak: Interpretasi tentang HAM serta ayat-ayat yang berkaitan dengan perempuan hanya dipandang sebelah mata dan lebih banyak muatan politik belaka.Kaum perempuan selalu menjadi objek kekerasan dan tidak dipandang sebagai manusia, dimana dalam kelas sosial selalu menjadi objek kekerasan, seperti kekerasan terhadap perkawinan, kejahatan pelacuran, banyaknya janda-janda yang masih dibawah umur. Konsep HAMitu seolaholah hanya berlaku bagi kaum laki-laki yang selalu merasa superioritas sedangkan kaum perempuan selalu tersubordinasi. KonsepHAM dalam Islam tentu tidak secara mudah diterima di negara Islam, hal demikian terjadikarena umat Islam selalu memiliki anggapan yang negatif bahwa HAM itu seolah-olah produk dari Barat yangakhirnya berdampakpada kesombongan intelektual serta kemalasan kita untuk mengkaji secara mendalam tentang HAM dalam Islam. Isu apakah HAM ada dalam Islam atau tidak, tentu melahirkan rumusan HAM pada akhir tahun 1948 ketika itu berhasil mencanangkan piagam hak asasi manusia. HAM adalah bagian dari Islam, karena Islam itu sangat universal berlaku untuk segala zaman, dan Islam juga tidak pernah memandang perbedaan antara laki-laki dan perempuan, akan tetapi karena pemahaman individu dan kelompok itulah yang membuat Islam itu menjadi inklusif dan terbatas, sehingga dalam mengartikan konsep HAM masih dipandang sebelah mata dalam dunia Islam. Konsep HAM itu sudah ada dalam tubuh Islam yang dimana dalam sejarah kehidupan dan perjalanan Nabi Muhammad SAW telah mengajarkan kita bahwa tidak ada perbedaan posisi kaum laki-laki dan perempuan, tidak ada diskriminasi satu sama lain dan terlebih lagi dalam konteks sekarang sejak munculnya konsep HAM yang mengusung equality antara laki-laki dan perempuan dimata hukum dan tidak ada diskriminasi antara satu sama lain, karenaIslam sesungguhnya sudah lebih ramah terhadap kaum perempuan.
\end{abstract}

Kata kunci: HAM, Perempuan, Islam 


\section{PENDAHULUAN}

Perbincangan kaumperempuan mungkin sering kita dengar dan kita baca,baik di media cetakmaupun di media elektronik, terutama tentang isu-isu gender yang masih belum selesai di perbincangkan bahkan masih menjadi kontrovesi dikalangan masyarakat muslim saat ini, dalam buku Perempuan Dan Ketidak. Adilan Sosial yangditulis oleh Mahatma Gandhi, mengatakan bahwa kaum perempuan selalu jadi objek kekerasan dan tidak dipandang sebagai manusia, dimana dalam kelas sosial selalu jadi objek kekerasan, seperti kekerasan terhadap perkawinan, kejahatan pelacuran, banyaknya janda-janda yang masih dibawah umur. ${ }^{2}$

Terlebih lagi seringnya terjadi kekerasan terhadap kaum perempuan tanpa ada analisis yang mendalam secara signifikan. Apakah kita tidak sadar bahwa bangsa ini telah sepakat mengusung pemerintahan yang demokratis sebagai sistem yang paling ideal dan didambakan oleh rakyat. Kehidupan masyarakat dapat dikatakan demokratis jika dalam terapannya menghargai hak asasi manusia secara adil dan setara, mengakui dan memajukan akan kebebasan, penghargaan terhadap perbedaan yang ada, termasuk pengakuan peran serta kedudukan perempuan yang masih dirugikan sebagai akibat dari peran-peran yang diterjemahkan secara sosial dan budaya.Berbicara tentang kedudukan kaum perempuan dalam Islam sesungguhnya islam sudah lebih ramah terhadap kaum perempuan, akan tetapi interpretasi tentang ayat-ayat yang berkaitan dengan perempuan hanya dipandang sebelah mata dan lebih banyak muatan politik belaka. Dimana dalam buku Qur'an Menurut Perempuan dijelaskan bahwa sesungguhnya perempuan itu jangan hanya dipandang sebelah mata akan tetapijauh dari itu, dimana sering terjadi tanggapan bahwa perempuan hanya dilihat dalam ranah hubungan sosial. Namun perempuan juga harus dilihat sebagai individu, karena al-Qur'an memperlakukan individu baik laki-laki dan perempuan itu sama. ${ }^{3}$ Yakni apapun yang al-qur'an katakan tentang hubungan antara allah dan individu tidak dalam bahasa gender. Dimana dalam al-qur'an sering dikatakan dengan istilah nafs. Di dunia ini setiap individu diberi tanggung jawab dan kemampuan. Kemampuan individu dinyatakan sebagai berikut: "allah tidak membebani nafs diluar kemampuannya. Ia mendapatkan pahala dari yang hanya dikerjakannya danmendapatkan siksa sesuai dengan yang dikerjakannya." (Q.S. 2:286).

2 Baca Mahatma Gandhi,Kaum Perempuan Dan Ketidak Adilan Sosial, (Yogyakarta: Pustaka Pelajar, 2011),510.

3 Amina Wadud,Qur'an And Womens: Rereading The Sacred Text From A Woman's Perspective, Terj. Abdullah Ali,Qur'an Menurut Perempuan: Meluruskan Bias Gender Dalam Tradisi Tafsir, (Jakarta: PT. Serambi Ilmu Semesta, 2001), 78. 


\section{Kedudukan Kaum Perempuan Dalam Islam}

Berbicara tentang kedudukan perempuan dalam Islam sebagai ajaran universal apakah sesungguhnya konsep HAM dan HAP menurut Islam; apakah HAM dan HAP itu produk Barat. Maka meihat komentar Ninik Rahayu wakil ketua Komisi Nasional Perempuan (Komnas Perempuan) periode 2007-2009, bercerita tentang perspektif pribadinya. Menurutnya sampai hari ini, Islam telah membuka ruang universalisme tentang hak-hak dasar manusia dan hak-hak dasar perempuan. Dalam pandangannya, Islam yang telah mendobrak gerbang dan membebaskan kaum perempuan dari belenggu jahiliyah, di mana perempuan diperlakukan sebagai barang milik, tanpa secuilpun hak atas dirinya sendiri. Kini jika ada banyak pendapat yang mengatakan bahwa konsep HAM dan HAP adalah produk dari Barat, hal itu dianggapnya tidak tepat.Konsep dasar Islam tentang HAM dan HAP itu tidak lahir dari negeri-negeri Barat, akan tetapi konsep itusudah ada didalam tubuh islam itu sendiri, seperti yang diajarkan oleh nabimuhammad SAW.Penghargaan dan penghormatan terhadap manusia tersebut, sesungguhnya dapat ditemukan konsepnya dalam sumber Islam, yaitu Alquran. Di antaranya:

"Dan sesunggubnya Kami telah memuliakan anak-anak. Adam. Kami angkat mereka di daratan dan lautan, Kami beri mereka rizki dari yang baik-baik serta Kami lebibkan mereka dengan kelebiban yang sempurna atas kebanyakan ciptaan Kami”. (Q.S. al Isra, 70)

"Wahai manusia Kami ciptakan kamu dari lelaki dan perempuan dan Kami jadikan kamu bersuku-suku dan berbangsa-bangsa agar kamu saling mengenal. Sesunggubnya yang paling mulia di antara kamu di sisi Allah adalah yang paling bertaqwa kepada-Nya”. (Q.S. al Hujurat, 13)

Dua ayat di atas menjelaskan kemuliaan dan kesetaraan martabat manusia tanpa melihat latarbelakang asal usulnya, warna kulit, jenis kelamin, bahasa dan sebagainya. Keunggulan yang dimiliki manusia satu atas manusia yang lain hanyalah pada aspek kedekatannya dengan Tuhan.

Pernyatan paling eksplisit lainnya mengenai kesetaraan hak dan kewajiban antara lelaki dan perempuan adalah:

"Sesunggubnya lelaki dan perempuan yang muslim, lelaki dan perempuan yang mukmin, lelaki dan perempuan yang tetap dalam ketaatannya, lelaki dan perempuan yang benar, lelaki dan perempuan yang sabar, lelaki dan perempuan yang khusyu', lelaki dan perempuan yang bersedekah, lelaki dan perempuan yang berpuasa, lelaki dan perempuan yang memelihara kehormatannya, lelaki dan perempuan yang banyak menyebut (nama) Allah, Allah telah menyediakan ampunan dan pahala yang besar". (QS. al Ahzab, 35). ${ }^{4}$

4 http://www.balitbangham.go.id. 
Hal itu berarti bahwa tidak ada pertentangan antara deklarasi HAM dan HAP dengan ajaran murni Islam. Hak-hak dasar manusia dan hak-hak dasar perempuan bukanlah konsep yang yang lahir dari Barat, ataupun konsep yang penuh kepentingan (misionari) Barat. Di dalam Islam hak-hak asasi perempuan dan manusia, sepenuhnya diakui dan dihormati.Demikian pula menurut Faqihuddin Abdul Kodir, bahwasanya Sahabat Umar bin Khottab r.a. menyatakan dalam berbagai kesempatan:

"Demi Allah, kami pada masa Jahiliyah tidak pernah memperbitungkan perempuan. Kemudian Allah menurunkan beberapa ayat tentang mereka, dan memberikan hak kepada mereka. Kami sadar lalu bahwa ternyata mereka juga memiliki bake secara otonom di mana kami tidak bisa lagi mengintervensi”. (Hadis Bukhari, kitab 77, bab 31, no. 5843)

Sedangkan menurut Faqihuddin beberapa teks hadis lain, secara eksplisit telah menyatakan hak-hak perempuan dalam kehidupan rumah tangga, di mana sebelumnya hak itu tidak dimiliki perempuan (Arab masa Jahiliyah). Teks hadis itu antara lain yang diriwayatkan Hakim bin Mu'awiyyah bin Haydah al-Qusyairy, bahwa kakeknya bertanya kepada Rasulullah saw:

"Apa saja hak-bak istri itu?". Rasul menjawab: "Kamu harus memberinya makan sebagaimana yang kamu makan, memberinya pakaian sebagaimana yang kamu pakai, tidak memukul wajahnya, tidak melecehkan dan tidak memusubinya dengan meninggalkan rumah”. (Lihat Ibn al-Atsir, Jami' al-Usbul, juz VII, hal. 357). ${ }^{5}$

Meskipun demikian, terkadang banyak pula interpretasi teks-teks agama yang saling bertentangan, antara mengekang dan membebaskan perempuan. Misalnya saja beberapa ulama melarang perempuan untuk datang dan memasuki masjid. Padahal di masjid itulah, pusat pendidikan, informasi, politik, dan ekonomi, di samping sebagai tempat ibadah tentunya.

Larangan tersebut biasanya didasarkan pada teks hadis tertentu mengenai ancaman terhadap perempuan yang suka menggoda dengan wewangian yang dikenakannya itu. Menurut Faqihuddin ${ }^{6}$, dalam hal ini Aisyah ra., Ummul Mukminin telah mengkritik fatwa itu, dengan mengatakan bahwa hak pergi ke masjid adalah sama, antara lelaki dan perempuan. Tidak boleh ada perempuan yang dilarang. Jika persoalannya 'mengganggu dan menggoda', maka harus ada penertiban untuk keduanya, lelaki dan perempuan, tidak hanya sepihak, perempuan saja. Relasi lelaki dan perempuan, harus ditertibkan dan diarahkan agar tidak terjerumus pada ketertarikan tubuh dan moral rendah. Namun untuk kerja keagamaan dan kemanusiaan, yang

5 Faqihuddin Abdul Kodir. Dalam Penegasan Nabi atas Hak-hak Perempuan. Dirasah Hadis, Swara Rahima Edisi 25. 2008.

$6 \mathrm{Ibid}$. 
didasarkan pada pikiran dan amal perbuatan yang baik, maka harus diberikan ruang yang seimbang di antara mereka.

Dalam pandangan Kiai Husein, seorang tokoh yang tertarik dengan isu-isu perempuan, mengatakan bahwa pertentangan-pertentangan tentang perempuan dalam teks agama yang cenderung diskriminatif. Maka dari itu, barangkali dibutuhkan cara bijak untuk menyikapinya. Diantara sikaptersebut adalah: Pertama, dengan menegasikan (menafikan) bentuk-bentuk diskriminasi antar manusia, termasuk dalam hal relasi lelaki dan perempuan. Hal ini karena diskriminasi tidak sejalan dengan prinsip Tauhid (Keesaaan Tuhan). Kedua, dengan menghindarkan kontradiksikontradiksi dalam teks-teks suci. Alquran telah menyatakan dalam ayatnya:

"...tidak datang kepadanya (Alquran) kebatilan, baik dari depan maupun dari belakang, yang diturunkan dari Tuban Yang Maha Bijaksana, Maha Terpuji”. (Q.S. Fusshilat, 42).

Barangkali cara terbaik untuk itu semua adalah dengan membaca kembali teksteks suci; al-Quran, dan hadit Nabi saw. maupun teks-teks kitab klasik karangan para ulama. Tentunya pembacaan ini melalui cara-cara yang memungkinkan semua untuk mampu mengatasi keadaan yang tampaknya saling bertentangan terebut.

Dan barangkali umat manusia membutuhkan ruang sosial baru yang memungkinkan perempuan dan lelaki dapat mengaktualisasikan dirinya di mana saja dengan tetap terjaga dan aman dari tindakan-tindakan yang dapat merendahkannya. Untuk itulah diperlukan nilai-nilai HAM dan HAP yang dapat menjamin kehidupannya dengan penuh damai, tanpa kekerasan, dan diskriminasi.

Menurut analisis penulis hal-hal yang perlu untuk kita perhatikan yakni bagaimana meningkatkan sikap ramah gender, serta meminimalisir pemikiran yang selalu merasa superioritas dan pendukung yang sangat fundamental dalam hal ini adalah regulasi serta undnag-undang hendaknya harus sesuai dengan kondisi serta hak-hak gender, dan untuk para pengambil kebijakan hendaknya lebih melihat secara jauh apa yang diinginkan masyarakat secara umum, karena menurut penulis, hukum serta pendiidkan kita seolah-olah jauh dari sikap humanitis, sehingga pola pemikiran yang selalu mengedepankan sikap diskriminasi masih terjadi, dan perlu diingat bahwa jumlah perempuan di Indonesia adalah separoh lebih dari jumlah penduduk. Potensi intelektual mereka yang semakin hari semakin meningkat merupakan potensi besar bagi pembangunan bangsa. Mereka juga memiliki aspirasi dan kepentingan yang tidak bisa diwakili oleh kaum lelaki. Dengan menegakkan hak-hak asasi mereka sebagai manusia, dan menghargainya sama dengan lelaki, semoga akan lahir suatu kehidupan yang lebih adil dan setara. 


\section{Perempuan dalam Perspektif HAM}

Sebelum kita lebih jauh membahas kedudukan perempuan dimata HAM itu seperti apa, alangkah baiknya penulis memberikan pemaparan sejarah singkat tentang HAM agar makna dantujuan dari makalah ini tidak terlalu kabur. Konsep $\mathrm{HAM}^{7}$ sebenarnya muncul pada akhir tahun 1948 ketika itu berhasil mencanangkan piagam hak asasi manusia. Memang ketika perang dunia II (1 september 1939) sangat berpengaruh terhadap kelahiran konsep HAM itu sendiri. Dalam beberapa konsep banyaknya yang menyebutkan bahwa konsep HAM itu berlaku secara universal dimana dalam pasal 7 yang menyebutkan bahwa "Semua orang sama di depan hukum dan berhak atas perlindungan hukum yang sama tanpa diskriminasi. Semua berhak atas perlindungan yang sama terhadap setiap bentuk diskriminasi yang bertentangan dengan Pernyataan ini dan terhadap segala hasutan yang mengarah pada diskriminasi semacam itu. ${ }^{8}$ Ketentuan tersebut menggunakan istilah "semua orang atau all buman beings" tanpa pembedaan jenis kelamin, yang menggambarkan bahwa hak asasi manusia melekat pada setiap orang, baik pria maupun wanita. Dalam konteks HAM itu sendiri terdapat komponen-komponen seperti:

1. Kovenan Internasional tentang Hak-hak Sipil dan Politik

Terdapat dalam Pasal 14 ayat (1) yang menyebutkan bahwa "Semua orang mempunyai kedudukan yang sama di hadapan pengadilan dan badan peradilan. "Terdapat juga dalam Pasal 26 yang menyebutkan bahwa "Semua orang berkedudukan sama di hadapan hukum dan berhak atas perlindungan hukum yang sama tanpa diskriminasi apapun. Dalam hal ini hukum harus melarang diskriminasi apapun, dan menjamin perlindungan yang sama dan efektif bagi semua orang terhadap diskriminasi atas dasar apapun seperti ras, warna, jenis kelamin, bahasa, agama, politik, , asal-usul kebangsaan atau sosial, kekayaan, kelahiran atau status lain."

Dua pasal dalam ICCPR diatas, menunjukkan bahwa tidak ada pembedaan apapun, termasuk jenis kelamin terhadap hak wanita untuk memperoleh kesamaan di depan hukum dan melakukan perbuatan hukum.

2. Konvensi tentang Penghapusan Segala Bentuk Diskriminasi Terhadap Perempuan

Pasal 15 yang menyebutkan bahwa: 1.States Parties shall accord to women equality with men before the law; 2.States Parties shall accord to women, in civil matters, a legal capacity identical to that of men and the same opportunities to

7 Piet Go, O . Cam dkk,Etos Dan Moralitas Politik, (Yogyakarta: Kanisius, 2003), 35.

8 United Nations, Universal Declaration of Human Rights, disahkan dalam Resolusi Rapat Majelis Umum PBB No 217 A (III) tanggal 10 Desember 1948, diratifikasi Indonesia Tahun 1999. 
exercise that capacity. In particular, they shall give women equal rights to conclude contracts and to administer property and shall treat them equally in all stages of procedure in courts and tribunals; 3.States Parties agree that all contracts and all other private instruments of any kind with a legal effect which is directed at restricting the legal capacity of women shall be deemed null and void; 4.States Parties shall accord to men and women the same rights with regard to the law relating to the movement of persons and the freedom to choose their residence and domicile. Pasal 15 ini menegaskan bahwa wanita memiliki hak yang sama dengan pria di depan hukum. Begitu pula dalam hukum perdata, wanita dan pria memiliki hak yang sama, termasuk hak membuat perjanjian, mengelola kekayaan, dan beracara di pengadilan.

3. Instrumen HAM Nasional Mengenai Hak Wanita Atas Kesamaan di Hadapan Hukum.

Di dalam undang dasar republik indonesia sendiri ada beberapa undang-undang yang melindunga bagaimana HAM itu berlaku hanya dalam pembedaan jenis kelamin seperti yang tercantum dalam:

a. Undang-Undang Dasar 1945

Perlindungan hak wanita atas kesamaan di depan hukum, diakui dalam konstitusi tertulis Indonesia, yaitu Undang-undang Dasar 1945 Pasal 28D menyatakan bahwa "Setiap orang berhak atas pengakuan, jaminan, perlindungan, dan kepastian hukum yang adil serta perlakuan yang sama di hadapan hukum. 'dalam pasal ini, istilah "setiap orang" yang berarti bahwa perlakuan yang sama di hadapan hukum berlaku bagi setiap orang, pria dan wanita, tanpa pembedaan jenis kelamin.

Selain itu, dalam pasal 27 ayat (1) juga dinyatakan bahwa "Segala warga negara bersamaan kedudukannya di dalam hukum dan pemerintahan dan wajib menjunjung hukum dan pemerintahan itu dengan tidak ada kecualinya". Dalam pasal 27 ayat (1) juga menggunakan istilah "segala warga negara", yang berarti kedudukan di dalam hukum dan pemerintahan tidak mengenal pembedaan jenis kelamin dan gender. ${ }^{10}$

b. Undang-Undang no 39 tahun 1999 tentang Hak Asasi Manusia

Dalam Pasal 17 dinyatakan bahwa "Setiap orang. tanpa diskiriminasi, berhak untuk memperoleh keadilan dengan mengajukan permohonan. pengaduan, dan gugatan.’Undang-undang ini merupakan pengejawantahan semangat Deklarasi Universal Hak Asasi Manusia, yang menyatakan bahwa hak atas keadilan merupakan hak asasi yang melekat kepada setiap manusia. Pasal ini juga menggunakan istilah

9 Indonesia, Undang-undang Dasar 1945, pasal 28D.

10 Nur Said, Perempuan Dalam Himpitan Teologi Dan HAM, (Yogyakarta: Pilar Media, 2005), 57. 
"setiap orang" yang menunjukkan bahwa tidak ada diskriminasi apapun, termasuk gender untuk memperoleh keadilan melalui hukum.Selain itu, dalam pasal 29 ayat (2) dinyatakan bahwa "Setiap orang berhak atas pengakuan di depan hukum sebagai manusia pribadi di mana saja ia berada." Yang dimaksud setiap orang disini berarti setiap insan manusia yang tidak dibatasi oleh sekat-sekat apapun, termasuk gender. Hal ini dipertegas dalam UU HAM ini, yang menyebutkan bahwa "Hak wanita dalam Undang-undang ini adalah hak asasi manusia." Pasal ini memperjelas kedudukan wanita yang dijamin haknya secara penuh dalam undang-undang ini, termasuk haknya untuk memperoleh kesamaan di depan hukum.

Pengaturan lebih khusus mengenai hak wanita atas kesamaan di depan hukum, diatur dalam Pasal 50, yang selengkapnya berbunyi "Wanita yang telah dewasa dan atau telah menikah berhak untuk melakukan perbuatan hukum sendiri, kecuali ditentukan lain oleh hukum agamanya." Hal ini menghapus keraguan terhadap kecakapan wanita melakukan perbuatan hukum atas kehendaknya sendiri. Pembatasan menurut hukum agama yang tercantum dalam pasal tersebut, merupakan perwujudan dari pemahaman partikularistik relatif yang merupakan pemahaman jaminan perlindungan Hak Asasi Manusia. Dimana seperti yang dijelaskan di atas bahwa kedudukan perempuan dimata HAM itu sama dan tidak ada perbedaan maupun diskriminasi antara satu sama lainnya. ${ }^{11}$

Jadi jelas sudah bagaimana posisi dan kedudukan kaum perempuan dimata hukum yang mengaturnya, sehingga tidak ada jalan untuk kita melakukandiskriminasi terhadap kaum perempuan karena kita sama-sama mmiliki hak dan tanggung jawab secara individual. Akan tetapi yang menjadi persoalan dewasa iniadalah pola pikir kita yang masih jauh dari keramahan serta sikap kita yang kurang ekslusif dalam melihat realita di tengah-tengah masyarakat. Mungkin sebagai contoh peristiwa mei 1998 menunjukkan secara sangat dramatik bagaimana perempuan minoritas mengalami multiple descrimination dan manifestasi agresi rasial yang berbeda dengan laki-laki. Ditengah-tengah kerusuhan massal perempuan etnis tionghoa diserang karena identitas etnisnya dan diperkosa karena identitas seksualnya. Manifestasi agresi rasial berbentuk penjarahan dan pembakaran sama-sama dialamioleh kaum perempuan sebagaimana saudara laki-lakinya. Diskriminasi perempuan madura dalam kerusuhan sambas (kalimantan barat) sebagaimana perempuan ambon, poso, dan juga timor timur. Apa sebenarnya yang melandasi terjadinya diskriminasi terhadap kaum perempuan, hal ini tidak lain karena kurangnya kesadaran masyarakat terhadap HAM itu sendiri, seolah-olah HAM hanya berlakubagi kaum laki-laki yang merasa superioritas dan perempuan adalah makhluk kedua setelah laki-laki yang dapat

11 Ibid., 62. 
ditindas sesuka hati. Oleh karena itu hendaknya kita selalu memperhatikan regulasiregulasi yang telah diatur untuk kepentingan bersam dan berlaku secara universal seperti konsep yang dianut oleh HAM itusendiri.

\section{PENUTUP}

Sesungguhnya Islam itu sangat universal berlaku untuk segala zaman, dan Islam juga tidak pernah memandang perbedaan antara laki-laki dan perempuan, akan tetapi karena pemahaman individu dankelompok itulah yang membuat Islam itu menjadi inklusif dan terbatas,sehingga dalam mengartikan konsep Hak Asasi Manusiapun masih dipandang sebelah mata dalam dunia Islam itu sendiri. Konsep HAM itu seolah-olah hanya berlaku bagi kaum laki-laki yang selalu merasa superioritas sedangkan kaum perempuan hanya makhluk kedua setelah laki-laki yang selalu tersubordinasi. Dan apa sesungguhnya yang melatar belakangi konsepHAM ituberkembang dinegara Islam, apakahkarena rasa kesombongan intelektual serta kemalasan kita untuk mengkaji secara mendalam tentang HAM itu sendiri. Dan tiada lain umat Islam selalu memiliki anggapan yang negatif bahwa HAM itu seolaholah produk dari Barat.Pada dasarnya konsep HAM itu sudah ada dalam tubuh islam sendiri yang dimana dalam sejarah kehidupan dan perjalanan Nabi Muhammad SAW,beliaun telah mengajarkan kita bahwa tidak ada perbedaan posisi kaum laki-laki dan perempuan, tidak ada diskriminasi satu sama lain dan terlebih lagi dalam konteks sekarang sejakmunculnya konsep HAM pada tahun 1947-1948 yang mengusung equality antara laki-laki dan perempuan dimata hukum dan tidak ada diskriminasi antara satu sama lain. 


\section{DAFTAR PUSTAKA}

Faqihuddin Abdul Kodir, Dalam Penegasan Nabi Atas Hak-hak Perempuan

(Dirasah Hadis, Swara Rahima Edisi 25. 2008)

Gandhi Mahatma,Kaum Perempuan Dan Ketidak. Adilan Sosial, (Yogyakarta: Pustaka Pelajar, 2011)

http://www.balitbangham.go.id.

Indonesia, Undang-undang Dasar 1945, pasal 28D

Said Nur,Perempuan Dalam Himpitan Teologi Dan HAM, Yogyakarta: Pilar Me dia, 2005)

United Nations, Universal Declaration of Human Rights, disahkan dalam Resolusi Rapat Majelis Umum PBB No 217 A (III) Tanggal 10 Desember 1948, diratifikasi Indonesia Tahun 1999

Piet Go, O . Cam dkk. Etos Dan Moralitas Politik, (Yogyakarta: Kanisius, 2003)

Amina Wadud,Qur'an And Womens: Rereading The Sacred Text From A Woman's Perspective, Terj. Abdullah Ali. Qur'an Menurut Perempuan: Meluruskan Bias Gender Dalam Tradisi Tafsir, (Jakarta: PT. Serambi Ilmu Semesta, 2001) 